\title{
The time dependent effect of various irrigation systems on the reduction of $E$. faecalis in experimentally infected root canals
}

\author{
Ertuğrul Karataş, ${ }^{1}$ Muhammed Hamidullah Uyanık, ${ }^{2}$ Aneesh Abbas,, Damla Özsu, ${ }^{1}$ Hakan Arslan ${ }^{1}$ \\ 'Department of Endodontics, Ataturk University Faculty of Dentistry, Erzurum, Turkey \\ ${ }^{2}$ Department of Microbiology, Ataturk University Faculty of Medicine, Erzurum, Turkey
}

\begin{abstract}
Objective: To compare the time dependent effect of Vibringe, EndoVac, non-activated SAF, passive ultrasonic irrigation (PUI), and a conventional syringe on the reduction of E. faecalis in experimentally infected root canals.

Methods: Sixty human mandibular premolar teeth with straight roots and single root canals, were infected with E. faecalis. One group served as a control group and in the control group, neither irrigation nor instrumentation procedures were performed. The root canals were irrigated with Vibringe, EndoVac, non-activated SAF, passive ultrasonic irrigation (PUI) and conventional syringe using distilled water. After the irrigation procedures, samples were taken from root canals with paper points and incubated in blood agar plates. The colonies grown on the blood agar were counted and interpreted as colony forming units per millilitre.
\end{abstract}

Results: Intergroup analysis revealed significant differences between the control and experimental groups $(p<0.001)$. The root canal irrigation with the conventional needle for four minutes was more effective than two minutes at reducing the number of cfu counts.

Conclusion: It can be concluded that the irrigation time with the conventional needle significantly effects the reduction of $E$. faecalis in the root canal.

Keywords: EndoVac; SAF; time-dependent; vibringe.

$\mathrm{T}_{\mathrm{r}}$ He presence of bacteria in the root canal system is the primary etiological factor in the development of pulp and periapical diseases. ${ }^{[1-3]}$ One of the main objectives of endodontic treatment is the complete elimination of intracanal bacteria or at least to reduce them to the levels that are compatible with periradicular tissue healing. ${ }^{[4]}$

Although mechanical preparation of the infected root canals is particularly effective in reducing the presence of bacteria in the main root canal, it is not reliable in rendering canals bacteria free. ${ }^{[5,6]}$ Studies have shown that the use of irrigants and medicaments provides an additional antibacterial effect in combination with mechanical preparation. ${ }^{[7-}$ ${ }^{9]}$ However, the incidence of negative cultures ranges from $40 \%-60 \%$ of the cases after chemo-mechanical preparation with different instrumentation techniques and instruments, and conventional irrigation with different irrigants. ${ }^{[10-16]}$ In this regard, to improve root canal disinfection, various irrigation systems were introduced in endodontics.

Correspondence: Dr. Ertuğrul Karataş. Atatürk Üniversitesi, Diş Hekimliği Fakültesi,

Endodonti Anabilim Dalı, Erzurum, Turkey.

Tel: +90 442 - 2311746 e-mail: dtertu@windowslive.com

Submitted: June 28, 2015 Accepted: July 16, 2015 
The Self-Adjusting File (SAF) (ReDent Nova, Ra'anana, Israel) is a hollow and flexible instrument that removes dentine with a back-and-forth grinding motion. An advantage of the SAF system is that the irrigant is continuously delivered throughout instrument operation by a peristaltic pump. It can also be used as a non-activated device for the irrigation of root canals without activating the file. ${ }^{[17,18]}$

The Vibringe System (Vibringe B. V. Corp, Amsterdam, Netherlands) is an irrigation device that allows continuous sonic irrigation of the canal system during endodontic treatment. However, the effects of the Vibringe and non-activated SAF on reduction of Enterecoccus faecalis (E. faecalis) in experimentally infected root canals have not been reported.

The irrigation time also has an effect on the disinfection of experimentally infected root canals. Although there are studies that have evaluated the efficacy of irrigation solutions and their optimal concentration, contact time and temperature for clinical use, ${ }^{[19-21]}$ a study that evaluates the effect of irrigation systems and their optimal usage time on the reduction of E. faecalis in experimentally infected root canals without using any antibacterial irrigation solution has not been reported. Therefore, the aim of the present study was to compare the time dependent effect of Vibringe, EndoVac (Discus Dental, Smart Endodontics, Culver City, CA, USA), non-activated SAF, passive ultrasonic irrigation (PUI) (NSK, Nakanishi Inc. Kanuma, Japan), and a conventional syringe on the reduction of E. faecalis in experimentally infected root canals. The null hypothesis is that there is no difference between these systems and irrigation time on eliminating E. faecalis from experimentally infected root canals.

\section{Materials and methods}

Sixty human mandibular premolar teeth with straight roots and single root canals, extracted for reasons not related to this study, were selected. All teeth had complete root development and the presence of a single canal was established by radiographs taken in both mesiodistal and buccolingual projections. Only those teeth with root canals presenting a $>2.5: 1$ ratio between the buccolingual and mesiodistal dimensions at a level $5 \mathrm{~mm}$ from the apex were included in the experiment. The crowns were sectioned with a highspeed bur (KGSorensen, Barueri, SP, Brazil) under a copious water spray and the root lengths were standardized to approximately $14 \mathrm{~mm}$. The working length (WL) was obtained by measuring the length of the initial instrument (size 15) at the apical foramen minus $1 \mathrm{~mm}$. Root canals were instrumented to a size $20 \mathrm{~K}$-file (Mani Inc. Tochigi, Japan) under copious irrigation with distilled water. Composite resin was used to seal the apex and the root surfaces were covered with nail varnish to prevent the leakage of bacteria. To simplify the manipulation during contamination and irrigation procedures, specimens were mounted vertically up to the cemento-enamel junction in blocks made of acrylic resin. All samples were placed in autoclave sachets and sterilized in autoclave at $121{ }^{\circ} \mathrm{C}$ for 20 minutes. The effectiveness of the the sterilization was checked with an indicator placed in the sachets.

The E. faecalis strain (ATCC 29212) was used to contaminate the root canals. A microbial suspension containing approximately $10^{8}$ colony forming units $(\mathrm{cfu}) / \mathrm{mL}$ was prepared by mixing a pure culture of E. faecalis and sterile phosphate-buffered saline. The density of $0.5 \mathrm{McF}$ arland was measured by the densitometer (BioMérieux, Lyons, France). The canals were contaminated with $20 \mu \mathrm{L}$ of the suspension containing $E$. faecalis, using automatic micropipets, and size $15 \mathrm{~K}$-files were used to carry the suspension to the WL. The acrylic blocks containing teeth were then incubated at $37^{\circ} \mathrm{C}$ for 48 hours.

After contamination, all teeth were randomly divided into six groups: control, needle, non-activated SAF, Vibringe, Endo Vac, and PUI.

In all the groups, except the control group, the root canals were instrumented using Protaper Universal rotary files (Dentsply Maillefer, Ballaigues, Switzerland) to a size of $40, .06$ taper. The following sequence was used: F2, F3 and F4 files (full WL).

In the control group, neither irrigation nor instrumentation procedures were performed.

In the needle group, the irrigation was performed with a syringe and a 30 gauge (approximately $0.25 \mathrm{~mm}$ ) closed-end tip and side-port opening needle (Canal Clean, Biodent, South Korea). The root canals were irrigated with the needle for one minute using $1 \mathrm{~mL}$ of distilled water between each file. Following the use of the last instrument, the needle was used for two minutes using $2 \mathrm{~mL}$ of distilled water as a final rinse. The first sample was taken from the root canal as described later. The irrigation procedure was performed for two more minutes and a second sample was taken. The flow rate of the irrigating solution was $1 \mathrm{~mL} \mathrm{~min}{ }^{-1}$. A new needle was used for all teeth to prevent the root canals from cross contamination.

In the non-activated SAF group, the SAF system was used only for irrigation with a VATEA peristaltic pump as described previously. ${ }^{[18]} \mathrm{A} 1.5 \mathrm{~mm}$ diameter and $25 \mathrm{~mm}$ length SAF file was operated for one minute at a rate of 1 $\mathrm{mL} /$ minute between each file. After the last instrument, the SAF system was used for two minutes as a final rinse and the first sample was taken from the root canal. 
The SAF system was used again for two more minutes at the same flowing rate and a second sample was taken from the root canal. A new SAF instrument was used for all teeth to prevent the root canals from cross contamination.

In the Vibringe group, the root canals were irrigated and sonically activated via the Vibringe system (Vibringe B. V. Corp, Amsterdam, Netherlands) at a $1 \mathrm{~mL} /$ minute flowing rate with the same irrigation needle used for the needle group. The Vibringe system was used for one minute between each file and, after the last instrument, it was used for two minutes as a final rinse and the first sample was taken from the root canal. For the second sample, the Vibringe system was used for two more minutes at the same flowing rate. A new needle was used for all teeth to prevent the root canals from cross contamination.

In the EndoVac group, the master delivery tip of the EndoVac system was used for irrigation at a $1 \mathrm{~mL} /$ minute flowing rate and the solution was evacuated via the microcannula. After every six seconds, the microcannula was withdrawn $2 \mathrm{~mm}$ for 6 seconds to evacuate micro bubbles and insure a constant irrigant exchange. Then, the microcannula was used $1 \mathrm{~mm}$ short of the WL. The root canals were irrigated with the EndoVac for one minute between each file, and after the last instrument, it was used for two minutes as a final rinse. The first sample was then taken from the root canal. The second sample was collected after using the Vibringe system was for two more minutes at the same flowing rate. A new microcannula was used for all teeth to prevent the root canals from cross contamination.

In the PUI group, the root canals were irrigated with the same irrigation needle used for the needle group at a $1 \mathrm{~mL} /$ minute flowing rate between each file. After each irrigation procedure, a U-file ultrasonic tip (size 15, 0.02 taper) (NSK Varios; Nakanishi Inc., Tochigi, Japan) was placed $1 \mathrm{~mm}$ short of the WL and activated at a frequency cycle of $28 \mathrm{kHz}-32 \mathrm{kHz}$ per second for one minute. Following the use of the last instrument, the root canals were irrigated for two minutes as a final rinse. The ultrasonic tip was activated at the same frequency for two minutes and the first sample was taken from the root canal. For the second sample, the root canals were irrigated and the solution was activated for two more minutes at a $1 \mathrm{~mL} /$ minute flowing rate and a frequency cycle of $28 \mathrm{kHz}-32 \mathrm{kHz}$ per second, respectively. A new ultrasonic tip and needle was used for all teeth to prevent the root canals from cross contamination.

In all groups, a total of $5 \mathrm{~mL}$ of distilled water was used for irrigation and the needle tip was placed $1 \mathrm{~mm}$ short of the WL in needle, Vibringe, and PUI groups.

After the irrigation procedures, three paper points were placed into the root canal at WL and each paper point remained in the root canal for one minute. Paper points were transferred into tubes containing $1 \mathrm{~mL}$ of $0.85 \%$ sterile saline and then vortexed thoroughly for one minute. After 10 fold serial dilutions in sterile saline, aliquots of $0.1 \mathrm{~mL}$ were plated onto blood agar plates and incubated at $37^{\circ} \mathrm{C}$ for 24 hours. The colonies grown on the blood agar were counted and interpreted as colony forming units per millilitre $(\mathrm{cfu} / \mathrm{mL})$.

The data were analyzed using the two-way analysis of variance (ANOVA) and Tukey's post hoc tests in order to detect the effect of the independent variables (groups and time), and their interactions on the reduction of the cfu counts $(\mathrm{p}=.05)$. All statistical analyses were realized by using software (SigmaStat for Windows Version 3.5; Systat Software, Inc., Erkrath, Germany) at a significance level of .05 and a confidence interval of $95 \%$.

\section{Results}

The two-way ANOVA indicated that the cfu count was signiŞcantly affected by the groups $(\mathrm{p}<.001)$, and by the time ( $p>05)$. However, there were no a statistically significant interactions between the groups and time $(\mathrm{p}=.605)$ (Table 1).

The number of cfu counts of E.faecalis after irrigation with the conventional needle, nonactivated SAF, Vibringe, EndoVac, and PUI for two and four minutes is presented in Fig 1. Intergroup analysis revealed significant differences between the control and experimental groups. All irrigation systems were significantly effective when compared with the control group $(\mathrm{p}<0.001)$. However, there were no statistically significant differences between experimental groups $(\mathrm{p}<0.05)$.

Table 1. Two way analysis of variance

\begin{tabular}{lccccc} 
Source of variation & DF & SS & MS & F \\
Group & 5 & 87813549.074 & 17562709.815 & 282.042 & $<0.001$ \\
Time & 1 & 253267.593 & 253267.593 & 0.047 \\
Group $\times$ Time & 5 & 226215.741 & 45243.148 & 0.727 & 0.605 \\
Residual & 96 & 5977911.111 & 62269.907 & \\
Total & 107 & 94270943.519 & 881036.855 & \\
\hline
\end{tabular}

DF: Degrees of freedom; SS: Sum of squares; MS: Mean squares 


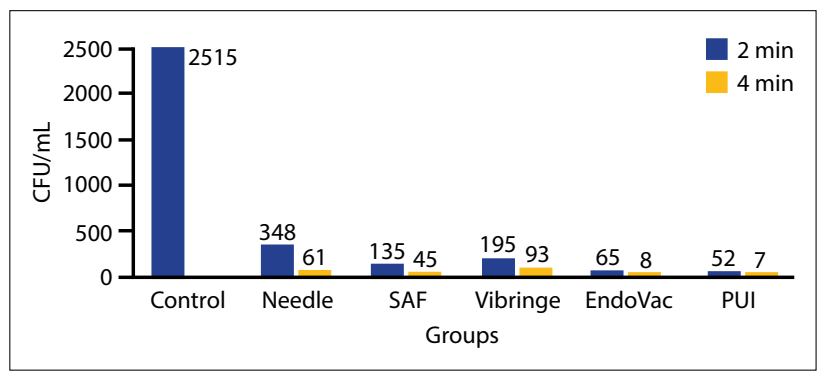

Fig. 1. The number of cfu of E. faecalis after irrigation of the root canals with different systems for two and four minutes.

Intragroup analyses revealed that the root canal irrigation for two and four minutes yielded a significant bacterial reduction. In the conventional needle group, a significant difference was observed when comparing two and four minutes $(\mathrm{p}<0.05)$. The root canal irrigation with the conventional needle for four minutes was more effective than two minutes at reducing the number of cfu counts. There were no significant differences when comparing two minute and four minute irrigations with nonactivated SAF, Vibringe, EndoVac, and PUI groups in terms of bacterial reduction in the root canals.

\section{Discussion}

The foundation of clinical endodontics is the microbial control ${ }^{[22]}$ and the prognosis of endodontic treatment depends on root canal disinfection. ${ }^{[12]} \mathrm{Du}$ et al. ${ }^{[23]}$ indicated that the killing of bacteria in infected dentin by root canal disinfecting solutions is time-dependent. Although there are many studies that have evaluated the efficacy of different irrigation techniques on root canal disinfection, ${ }^{[22,24-26]}$ the time-dependent effect of Vibringe, EndoVac, nonactivated SAF, PUI, and the conventional syringe on the reduction of E. faecalis in experimentally infected root canals has not been studied. Therefore, in the current investigation, the time-dependent ability of five different irrigation techniques in reducing E. faecalis from root canals during chemo-mechanical instrumentation was evaluated.

The results of the present study demonstrated that all techniques provided a significant reduction in the bacterial populations when compared with the control group and there were no statistically significant differences among the experimental groups. Previously, the ability of nonactivated SAF irrigation in reducing $E$. faecalis has not been studied. Therefore, a direct comparison cannot be done with studies in which an activated SAF was used. Further studies should be conducted to confirm the findings of the present study.

In the present study, there was no significant difference between the nonactivated SAF irrigation for two or four minutes. This finding is an accordance with the result of a previous study which evaluated the time-dependent antibacterial effect of the SAF and found that there was no significant difference when comparing the SAF instrumentation for two minutes with four minutes. ${ }^{[20]}$

The EndoVac system was claimed to be able to increase cleaning and disinfection of the root canal. ${ }^{[27,28]}$ Several studies found better results with the EndoVac system than with conventional or ultrasonic irrigation in terms of the cleaning of the root canal..$^{[29-32]}$ On the other hand, Brito et al. ${ }^{[33]}$ compared the effectiveness of three irrigation systems in reducing intracanal E. faecalis populations and concluded that there was no significant difference between the EndoVac and other irrigation techniques. Miranda et al. ${ }^{[26]}$ also compared the antimicrobial efficacy of the conventional needle irrigation, EndoVac system and phoyodynamic therapy against intracanal $E$. faecalis and found that there was no significant difference among the the groups. In the present study, the EndoVac system provided similar results to those of other irrigation techniques. The critical methodological differences in the experimental models, such as the volume and type of irrigant, may explain such divergences amongst the studies that evaluated the antimicrobial efficacy of the EndoVac system.

The direct contact of the root canal irrigation solution with the bacteria in peripheral areas of the root canal is often impossible. ${ }^{[34]}$ Caron $^{[35]}$ reported that the sonic activation of the irrigant provides deeper penetration of the irrigant to all areas of the endodontic space. Although previous studies have demonstrated that sonic activation of the irrigant is more effective in reducing bacterial load in the root canal, ${ }^{[24,36]}$ one study reported that sonic activation of the irrigant is not better than needle irrigation at removing bacteria from the root canals. ${ }^{[33,37]}$

The possible influence of the size of the sonic or ultrasonic oscillating tip upon the irrigation has been stated. [33,38] The Vibringe system allows sonic oscillation of the needle via its specially designed disposable syringe, which is compatible with every irrigation needle. The differences between the size of the oscillating tip, type and amount of irrigant might have led to different results.

The use of ultrasonic to increase debridement and disinfection has been suggested.$^{[39-41]}$ However, in the present study, there was no significant difference between the PUI and other experimental groups, which is in accordance with a previous study that compared the PUI with needle irrigation.

The result of the present study showed that the root canal irrigation with the conventional needle for four minutes is more effective than two minutes in reducing 
the number of cfu counts. A recent study compared the effect of long-term exposure to endodontic disinfecting solutions on young and old E. faecalis biofilms in dentin canals and found that the proportion of killed bacteria was siginificantly lower after three minutes than after 10 and 30 minutes of exposure to the disinfecting agents. In the present study, an antibacterial irrigation solution was not used. The increased effect in four minute groups might be due to the volume of the irrigant, which has a mechanical influence on bacterial elimination. ${ }^{[42,43]}$

E. faecalis was selected for the study because it is known to be one of the most resilient bacteria and is associated with both primary and persistent endodontic infection, it can penetrate deep into dentinal tubules to form communities organized in biofilms and it has the ability to survive under unusual environmental stress. ${ }^{[44-48]}$

Since our aim was to assess the effect of the irrigation techniques in reducing E.faecalis from root canals, distilled water, which exerts no antibacterial effect on E.faecalis, was used as an irrigant in this study. ${ }^{[49]}$

\section{Conclusions}

In conclusion, the findings of this study revealed that all irrigation techniques tested were effective on the reduction of $\mathrm{E}$. faecalis in the root canals. The root canal irrigation with the conventional needle reduced more cfu counts in four minutes than it did in two minutes. Therefore, it can be concluded that the irrigation time with the conventional needle significantly affects the reduction of the bacterial count in the root canal. However, there were no differences between two and four minutes of irrigation with the nonactivated SAF, Vibringe, EndoVac and PUI groups in reducing E. faecalis counts from the root canals.

\section{Acknowledgement}

The authors deny any financial affiliations related to this study or its sponsors.

\section{References}

1. Bystrom A, Claesson R, Sundqvist G. The antibacterial effect of camphorated paramonochlorophenol, camphorated phenol and calcium hydroxide in the treatment of infected root canals. Endod Dent Traumatol 1985;1:170-5.

2. Kakehashi S, Stanley HR, Fitzgerald RJ. The Effects Of Surgical Exposures Of Dental Pulps In Germ-Free And Conventional Laboratory Rats. Oral Surg Oral Med Oral Pathol 1965;20:340-9.

3. Sundqvist G. Ecology of the root canal flora. J Endod 1992;18:427-30.

4. Siqueira JF Jr, Rôças IN. Clinical implications and micro- biology of bacterial persistence after treatment procedures. J Endod 2008;34:1291-1301.

5. Byström A, Sundqvist G. Bacteriologic evaluation of the efficacy of mechanical root canal instrumentation in endodontic therapy. Scand J Dent Res 1981;89:321-8.

6. Orstavik D, Haapasalo M. Disinfection by endodontic irrigants and dressings of experimentally infected dentinal tubules. Endod Dent Traumatol 1990;6:142-9.

7. Siqueira JF Jr, Rôças IN, Favieri A, Lima KC. Chemomechanical reduction of the bacterial population in the root canal after instrumentation and irrigation with $1 \%, 2.5 \%$, and 5.25\% sodium hypochlorite. J Endod 2000;26:331-4.

8. Siqueira JF Jr, Rôças IN, Santos SR, Lima KC, Magalhães FA, de Uzeda M. Efficacy of instrumentation techniques and irrigation regimens in reducing the bacterial population within root canals. J Endod 2002;28:181-4.

9. Shuping GB, Orstavik D, Sigurdsson A, Trope M. Reduction of intracanal bacteria using nickel-titanium rotary instrumentation and various medications. J Endod 2000;26:751-5.

10. Bystrom A, Sundqvist G. The antibacterial action of sodium hypochlorite and EDTA in 60 cases of endodontic therapy. Int Endod J 1985;18:35-40.

11. Sjögren U, Figdor D, Spångberg L, Sundqvist G. The antimicrobial effect of calcium hydroxide as a short-term intracanal dressing. Int Endod J 1991;24:119,25.

12. Sjögren U, Figdor D, Persson S, Sundqvist G. Influence of infection at the time of root filling on the outcome of endodontic treatment of teeth with apical periodontitis. Int Endod J 1997;30:297-306.

13. Siqueira JF Jr, Guimarães-Pinto T, Rôças IN. Effects of chemomechanical preparation with $2.5 \%$ sodium hypochlorite and intracanal medication with calcium hydroxide on cultivable bacteria in infected root canals. J Endod 2007;33:800-5.

14. Siqueira JF Jr, Magalhães KM, Rôças IN. Bacterial reduction in infected root canals treated with $2.5 \% \mathrm{NaOCl}$ as an irrigant and calcium hydroxide/camphorated paramonochlorophenol paste as an intracanal dressing. J Endod 2007;33:667-72.

15. Siqueira JF Jr, Rôças IN, Paiva SS, Guimarães-Pinto T, Magalhães KM, Lima KC. Bacteriologic investigation of the effects of sodium hypochlorite and chlorhexidine during the endodontic treatment of teeth with apical periodontitis. Oral Surg Oral Med Oral Pathol Oral Radiol Endod 2007;104:122-30.

16. McGurkin-Smith R, Trope M, Caplan D, Sigurdsson A. Reduction of intracanal bacteria using GT rotary instrumentation, 5.25\% $\mathrm{NaOCl}$, EDTA, and $\mathrm{Ca}(\mathrm{OH}) 2$. J Endod 2005;31:359-63.

17. Metzger Z, Teperovich E, Cohen R, Zary R, Paqué F, Hülsmann M. The self-adjusting file (SAF). Part 3: removal of debris and smear layer-A scanning electron microscope 
study. J Endod 2010;36:697-702.

18. Karatas E, Ozsu D, Arslan H, Erdogan AS. Comparison of the effect of nonactivated self-adjusting file system, Vibringe, EndoVac, ultrasonic and needle irrigation on apical extrusion of debris. Int Endod J 2015;48:317-22.

19. Gulsahi K, Tirali RE, Cehreli SB, Karahan ZC, Uzunoglu E, Sabuncuoglu B. The effect of temperature and contact time of sodium hypochlorite on human roots infected with Enterococcus faecalis and Candida albicans. Odontology 2014;102:36-41.

20. Alves FR, Almeida BM, Neves MA, Rôças IN, Siqueira JF $\mathrm{Jr}$. Time-dependent antibacterial effects of the self-adjusting file used with two sodium hypochlorite concentrations. J Endod 2011;37:1451-5.

21. Retamozo B, Shabahang S, Johnson N, Aprecio RM, Torabinejad M. Minimum contact time and concentration of sodium hypochlorite required to eliminate Enterococcus faecalis. J Endod 2010;36:520-3.

22. Harrison AJ, Chivatxaranukul P, Parashos P, Messer HH. The effect of ultrasonically activated irrigation on reduction of Enterococcus faecalis in experimentally infected root canals. Int Endod J 2010;43:968-77.

23. Du T, Wang Z, Shen Y, Ma J, Cao Y, Haapasalo M. Effect of long-term exposure to endodontic disinfecting solutions on young and old Enterococcus faecalis biofilms in dentin canals. J Endod 2014;40:509-14.

24. Bago I, Plečko V, Gabrić Pandurić D, Schauperl Z, Baraba A, Anić I. Antimicrobial efficacy of a high-power diode laser, photo-activated disinfection, conventional and sonic activated irrigation during root canal treatment. Int Endod J 2013;46:339-47.

25. Basmaci F, Oztan MD, Kiyan M. Ex vivo evaluation of various instrumentation techniques and irrigants in reducing E. faecalis within root canals. Int Endod J 2013;46:82330.

26. Miranda RG, Santos EB, Souto RM, Gusman H, Colombo AP. Ex vivo antimicrobial efficacy of the EndoVac system plus photodynamic therapy associated with calcium hydroxide against intracanal Enterococcus faecalis. Int Endod J 2013;46:499-505.

27. Schoeffel GJ. The EndoVac method of endodontic irrigation, part 2--efficacy. Dent Today 2008;27:82, 84, 86-7.

28. Schoeffel GJ. The EndoVac method of endodontic irrigation: safety first. Dent Today 2007;26:92, 94, 96 passim.

29. Nielsen BA, Craig Baumgartner J. Comparison of the EndoVac system to needle irrigation of root canals. J Endod 2007;33:611-5.

30. Hockett JL, Dommisch JK, Johnson JD, Cohenca N. Antimicrobial efficacy of two irrigation techniques in tapered and nontapered canal preparations: an in vitro study. J En$\operatorname{dod} 2008 ; 34: 1374-7$.

31. Shin SJ, Kim HK, Jung IY, Lee CY, Lee SJ, Kim E. Comparison of the cleaning efficacy of a new apical negative pressure irrigating system with conventional irrigation needles in the root canals. Oral Surg Oral Med Oral Pathol Oral Radiol Endod 2010;109:479-84.

32. Abarajithan $M$, Dham S, Velmurugan N, Valerian-Albuquerque D, Ballal S, Senthilkumar H. Comparison of Endovac irrigation system with conventional irrigation for removal of intracanal smear layer: an in vitro study. Oral Surg Oral Med Oral Pathol Oral Radiol Endod 2011;112:407-11.

33. Brito PR, Souza LC, Machado de Oliveira JC, Alves FR, De-Deus G, Lopes HP, et al. Comparison of the effectiveness of three irrigation techniques in reducing intracanal Enterococcus faecalis populations: an in vitro study. J Endod 2009;35:1422-7.

34. Haapasalo M, Shen Y, Qian W, Gao Y. Irrigation in endodontics. Dent Clin North Am 2010;54:291-312.

35. Caron G. Cleaning efficiency of the apical millimeters of curved canals usingthree different modalities of irrigant activation: an SEM study. Paris: Paris VII university; 2007.

36. Pasqualini D, Cuffini AM, Scotti N, Mandras N, Scalas D, Pera F, et al. Comparative evaluation of the antimicrobial efficacy of a 5\% sodium hypochlorite subsonic-activated solution. J Endod 2010;36:1358-60.

37. Townsend C, Maki J. An in vitro comparison of new irrigation and agitation techniques to ultrasonic agitation in removing bacteria from a simulated root canal. J Endod 2009;35:1040-3.

38. Ahmad M, Pitt Ford TR, Crum LA. Ultrasonic debridement of root canals: an insight into the mechanisms involved. J Endod 1987;13:93-101.

39. Plotino G, Pameijer CH, Grande NM, Somma F. Ultrasonics in endodontics: a review of the literature. J Endod 2007;33:81-95.

40. Spoleti P, Siragusa M, Spoleti MJ. Bacteriological evaluation of passive ultrasonic activation. J Endod 2003;29:12-4.

41. van der Sluis LW, Versluis M, Wu MK, Wesselink PR. Passive ultrasonic irrigation of the root canal: a review of the literature. Int Endod J 2007;40:415-26.

42. Sedgley C, Applegate B, Nagel A, Hall D. Real-time imaging and quantification of bioluminescent bacteria in root canals in vitro. J Endod 2004;30:893-8.

43. Sedgley CM, Nagel AC, Hall D, Applegate B. Influence of irrigant needle depth in removing bioluminescent bacteria inoculated into instrumented root canals using real-time imaging in vitro. Int Endod J 2005;38:97-104.

44. Haapasalo M, Orstavik D. In vitro infection and disinfection of dentinal tubules. J Dent Res 1987;66:1375-9.

45. Peciuliene V, Reynaud AH, Balciuniene I, Haapasalo M. Isolation of yeasts and enteric bacteria in root-filled teeth with chronic apical periodontitis. Int Endod J 2001;34:429-34.

46. Rôças IN, Siqueira JF Jr, Santos KR. Association of Enterococcus faecalis with different forms of periradicular 
diseases. J Endod 2004;30:315-20.

47. Pinheiro ET, Gomes BP, Ferraz CC, Sousa EL, Teixeira FB, Souza-Filho FJ. Microorganisms from canals of rootfilled teeth with periapical lesions. Int Endod J 2003;36:111.

48. Stuart CH, Schwartz SA, Beeson TJ, Owatz CB. Entero- coccus faecalis: its role in root canal treatment failure and current concepts in retreatment. J Endod 2006;32:93-8.

49. Ferrer-Luque CM, Bejarano I, Ruiz-Linares M, Baca P. Reduction in Enteroccocus faecalis counts - a comparison between rotary and reciprocating systems. Int Endod J 2014;47:380-6. 